\title{
Development and Evaluation of Physico-Chemical Properties of Kinnow - Aonla - Aloe Vera Blended Squash
}

\author{
Balaji Vikram* and Purnima Singh Sikarwar
}

Department of Horticulture, Sam Higginbottom University of Agriculture, Technology and Sciences, Allahabad (211007), India

*Corresponding author

\section{A B S T R A C T}

In present investigation the efforts have been made to prepare a therapeutic Squash made

\section{Keywords}

Kinnow, Aonla, Aloe vera, Squash, Storage

Article Info

Accepted:

04 March 2018

Available Online:

10 April 2018 from blend of kinnow-aonla and aloe vera juice extracts. Keeping the present view the investigation was carried out during 2015-16 under Complete Randomized Design with seven treatments and three replications in each. Squashes for different treatments were prepared from blending of kinnow-aonla juice (cv. NA-7) and aloe vera gel in different proportions by keeping TSS (50\%), acidity (1\%) and preservative value (KMS- $350 \mathrm{ppm}$ ) constant and stored at ambient temperature. Data was collected from initial level to 120 days after storage at 60 days intervals. During the storage studies total soluble solids, acidity, reducing sugar and total sugars increased whereas, vitamin $\mathrm{C}$, non- reducing sugar content and organoleptic score decreased with storage period. Based on experimental findings this study indicated that the treatment combination with $\mathrm{T}_{6}$ i.e. $25 \%$ Juice blend (consisting 5\% Kinnow $+70 \%$ Aonla juice $+25 \%$ Aloe vera gel) was found to be the most suitable in terms of quality, sensory scores and quality was remained acceptable up to 4 months (120 days) under ambient storage conditions.

\section{Introduction}

Aonla (Emblica officinalis Gaertn.) is also known as "Indian Gooseberry" and belongs to family Euphorbiaceae. Aonla fruit is used in both Ayurvedic and Unani system of Indian medicines and is the major constitutes in Chayvanprash and Trifla preparations. The fruit is highly nutritive and it is the richest source of vitamin C $(600 \mathrm{mg} / 100 \mathrm{~g})$ among fruits except Barbados cherry. However, it is not consumed much as fresh fruit as it is highly acidic and astringent in taste but several value added products like RTS, nectar
(Chandan et al., 2010) syrup, jam murabba, pickles and candy have been developed from the fruit.

Kinnow (Citrus reticulata) is first generation hybrid of king (Citrus nobilis) and willow leaf mandarin (Citrus deliciosa), and was developed by H.B. Frost at citrus research station, riverside, California. It was introduced and established in India by regional fruit research station, Abohar (Punjab) in 1969. Kinnow mandarin was introduced in India in the early 1940's. At present its cultivation has assumed great importance among north Indian 
growers and a large acreage of land is being brought under cultivation particularly in Punjab, Haryana, Rajasthan and Himachal Pradesh (Jain et al., 2003). Fully ripe fruits of kinnow have bright and deep attractive color, thin tight and compact skin. The fruits are juicy and the fresh juice extracted from the fruit harvested at appropriate stage of maturity, has refreshing flavor, characteristic pleasing aroma and thirst quenching properties, but also have the problem of short shelf life (Vikram and Prasad, 2014).

Aloe vera (Aloe barbadensis Miller) is perennial, drought resisting succulent plant of African origin belonging to the family Liliaceae. Aloe vera gel has revealed the presence of more than 200 active substances including vitamins, minerals, saponins and sterols. So, it is known as the 'Miracle plant'. Aloe vera comes under food related products and is being used as an ingredient for functional foods like jam and jelly, and beverages of orange, grape, cranberry, strawberry, raspberry, pineapple etc. (Malhotra et al., 2010). Aloe vera is used alone or more often in combination with a variety of fruit juices like aonla, raspberry etc. The medicinal values of aonla and aloe become more important as World Health Organization (WHO) estimated that 80 per cent of the developing countries rely on traditional medicine, mostly plant drugs for their primary health care needs of population. Development of kinnow-aonla beverages by incorporating aloe vera would be beneficial for growers, processors, marketing agencies and consumers because of nutritive, medicinal and therapeutic values of both aonla and aloe vera (Sasi et al., 2013).

\section{Materials and Methods}

The experiment was carried out under Post Harvest Laboratory in Department of Horticulture, Allahabad School of Agriculture,
SHIATS, Allahabad (U.P.) during the session 2015-16 under Complete Randomized Design with seven treatments and three replications in each. Standardization of blends for preparation of kinnow-aonla-aloe vera blended squash is mentioned in Table 1.

First of all $2 \mathrm{Kg}$ kinnow and $8 \mathrm{Kg}$. mature, healthy aonla fruits (cultivar, NA-7) were taken and graded. The fruits were washed in tap water to wash out adhering dirt and dust particles. Then fruits were grated by using Hand Carrot Grater and seeds were removed.

The grated materials were squeezing with help of muslin cloth and juice extracted. Juice was filled in glass bottles of $750 \mathrm{ml}$ capacity then pasteurized in autoclave at $100^{\circ} \mathrm{C}$ for 15 minutes and left throughout night for sedimentation (Fig. 1). About 3 litres pure aonla juice was obtained.

Kinnow fruits were washed in tap water and then were peeled and divided into halves. Fruit juice was extracted in a citrus juice extractor. After juice extraction the juices were kept for 24 hours in refrigerator $\left(4-2^{\circ} \mathrm{C}\right)$ for sedimentation. Then the clear juice was siphoned off and strained through muslin cloth. Kinnow and aonla raw juice was heated at $96^{\circ} \mathrm{C}$ for two minute to inactivate enzymes. Following the heating juice was filtered through 8-folded cheese cloth to eliminate particulates and then cardamom and ginger extract were heated at $96^{\circ} \mathrm{C}$ for 15 minute and also filtered through 8 -folded cheese cloth. 5 $\mathrm{Kg}$. mature and healthy aloe vea leaves were taken and leaved for 24 hours in vertical position in pan then washed. Cut them into small pieces and gel extracted by spoon. After that gel was homogenized through mixer and stained by muslin cloth. Gel was filled in glass bottles of $750 \mathrm{ml}$ capacity then pasteurized in autoclave at $100^{\circ} \mathrm{C}$ for 15 minutes and Left throughout night for sedimentation (Fig. 2). About 3 litres pure aloe vera gel was obtained. 
After juice extraction, $45 \%$ juice (blend of kinnow juice, aonla juice and aloe vera gel) was taken as per treatment combinations of the experiment. Calculated amount of sugars and citric acids were dissolved in water and adjust the total soluble solids at 50 per cent and acidity at 1.0 per cent. Then filtered the syrup and add the juice and preservative (KMS) $350 \mathrm{ppm}$ in the final products. The volume of final products taken for study was 21 litres (3 litres in each replication). The product (squash) was poured into sterilized glass bottles of $250 \mathrm{ml}$ capacity and capping was done. The filled bottles were pasteurized in an auto-clave at a temperature of $100^{\circ} \mathrm{C}$ for 15 minutes. Filled squash bottles were labeled properly and bottles of squash were stored in ambient conditions. First observation was recorded just after preparation of squash then after every 60 days intervals up to 120 days of storage.

The total soluble solids in the all treatments of kinnow-aonla-aloe vera blended squash samples were directly recorded by the help of hand refractrometer (Erma made Japan) for eight months storage at 60 days intervals. A hand refractometer is based on the principle of total refraction. The refractometer is first checked for accuracy before use by placing a few drops of distilled water on the prism in the specimen of the refractometer with the help of a glass rod after folding back the cover. A few drops of well homogenized sample were taken on prism of refractometer and direct reading was taken by reading the scale in meter and the results were expressed as per cent soluble solids ( ${ }^{\circ}$ Brix) and the values were corrected at $20^{\circ} \mathrm{C}$ as described in AOAC (1995). The $\mathrm{pH}$ of each kinnow-aonla-aloe vera blended squash sample was determined with the help of digital $\mathrm{pH}$ meter. The $\mathrm{pH}$ meter was standardized by using buffers of $\mathrm{pH} 7.00$ and 4.00 prior to recording $\mathrm{pH}$ of the samples. A sufficient quantity $(50 \mathrm{~mL})$ of Beverage was taken in $100 \mathrm{~mL}$ beaker and $\mathrm{pH}$ meter was used to record $\mathrm{pH}$ according to method described by Rangana (2001). The ascorbic acid in kinnow-aonla-aloe vera blended squash sample was determined by Freed (1966) sample solution equivalent to $0.2 \mathrm{mg}$ ascorbic acid $\mathrm{mL}^{-1}$ was prepared in water containing 3\% (w/v) metaphosphoric acid. It was titrated against standard 2, 6dichlorophenol indo-phenol (2, 6 DCIP) solution of $0.5 \mathrm{mg} \mathrm{mL}^{-1}$ concentration until the pink colour developed completely. The acidity in each sample was determined according to standard procedure given in AOAC (1995), $10 \mathrm{~mL}$ of Beverage along with $100 \mathrm{~mL}$ water was taken and then titrated with $0.1 \mathrm{~N} \mathrm{NaOH}$ using phenolphthalein as an indicator (1-2 drops) till light pink color was achieved.

\section{Sensory evaluation}

Kinnow-aonla-aloe vera blended squash was stored at room temperature for a period of 4 months by drawing samples at 0 and 60 days (60 days intervals). In kinnow-aonla-aloe vera blended squash storage intervals to evaluate changes in chemical and organoleptic parameters. Standard sensory evaluation procedures were followed to perform descriptive analysis; panelists were trained using repeated round table and individual evaluations of trial formulations of the control and value added samples. The products were also evaluated for sensory qualities viz., color, texture and taste and overall acceptability by a panel of 10 judges using a 9-point Hedonic scale where, score 1 is for 'dislike extremely' and 9 for 'like extremely'. Hedonic scale method as described by (Morten et al., 2010) was used for the organoleptic evaluation of kinnow-aonla-aloe vera blended squash during storage period.

\section{Statistical analysis}

Statistical analyses of data were done by using ANOVA on all experimental groups with 
three replicates each. The data were statistically analysed by using (CRD) design with 7 treatments of different value additions. Calculation was done as suggested by Fisher (2007).

\section{Results and Discussion}

The changes in chemical composition of kinnow-aonla-aloe vera blended squash is presented in Table 2. The TSS level of kinnow-aonla-aloe vera blended squash was found to increase significantly irrespective of the end of four months of storage. Observations recorded for change in total soluble solids were found higher in treatments $\mathrm{T}_{4}$ followed by treatments $\mathrm{T}_{3}$ and $\mathrm{T}_{2}$ having more amount of aloe vera gel because aloe vera gel have much higher total soluble solids value in comparison to aonla juice. Total soluble solids of the squash were observed to be increased gradually up to the end of experiment in all treatments under ambient storage conditions. Similar result was reported by Deka et al., (2004). TSS was found gradually increased with increase in storage period. This might be due to the conversion of polysaccharides into sugars during hydrolysis process. Increase in TSS might also be attributed to the reduction in moisture content of the product with storage. Increase in TSS with storage time was also reported by (Gaikwad et al., 2013) in their studies on lime juice; these results are also in agreement with previous studies of (Sasi et al., 2013) while studying on therapeutic ready to serve made from blend of Aloe vera, aonla and ginger juice.

Observations recorded for change in acidity was found higher in treatments $T_{6}$ followed by treatments $T_{5}$ and $T_{7}$ having more amount of aonla juice but least in treatments $\mathrm{T}_{4}$ having more amount of aloe vera gel because aonla juice have much higher acidity value in comparison to aloe vera gel. Acidity of the squash was observed to be increased gradually up to the end of experiment in all treatments under ambient storage conditions. The Acidity level increased significantly with corresponding decreased in $\mathrm{pH}$ irrespective of the treatments during storage. This is also an important attribute because tartness is a major factor in the acceptability of kinnow-aonlaaloe vera blended squash.

Acid gives the characteristic sourness to the product. Citric acid is the major acid in kinnow and aonla juice that enhance the characteristic flavor of kinnow-aonla-aloe vera blended squash. Highest acidity in aspartame treated sample was due to acidic nature of aspartame. This might be attributed to chemical reactions between organic constituents of fruit juice induced by temperature and action of enzymes during storage (Patel et al., 22). Similar observations were also reported by (Satwadhar et al., 2011). Aggarwal and Sandhu (1) in kinnow juice and Chandan et al., (8) in aonla RTS beverages. Similar result was reported by Kumar and Singh (2001).

Ascorbic acid of the squash was observed to be decreased gradually up to the end of experiment in all treatments under ambient storage conditions (Table 2). Marginal differences in ascorbic acid contents were observed in kinnow-aonla-aloe vera blended squash various treatments. Statistical Analysis showed that the results are highly significant for storage period (Table 2). Ascorbic acid contents decreased significantly at all storage intervals. These losses of ascorbic acid were attributed to the effect of processing, storage time and exposure to light. Highest ascorbic acid $(71.33 \%)$ was recorded in $\mathrm{T}_{5}$ and (66.52\%) followed by $\mathrm{T}_{6}$. The lowest $(14.55 \%)$ was observed in $\mathrm{T}_{4}$. The degradation of ascorbic acid in Morinda citrifolia juice may follow aerobic and an-aerobic pathways (Satwadhar et al., 2011). 


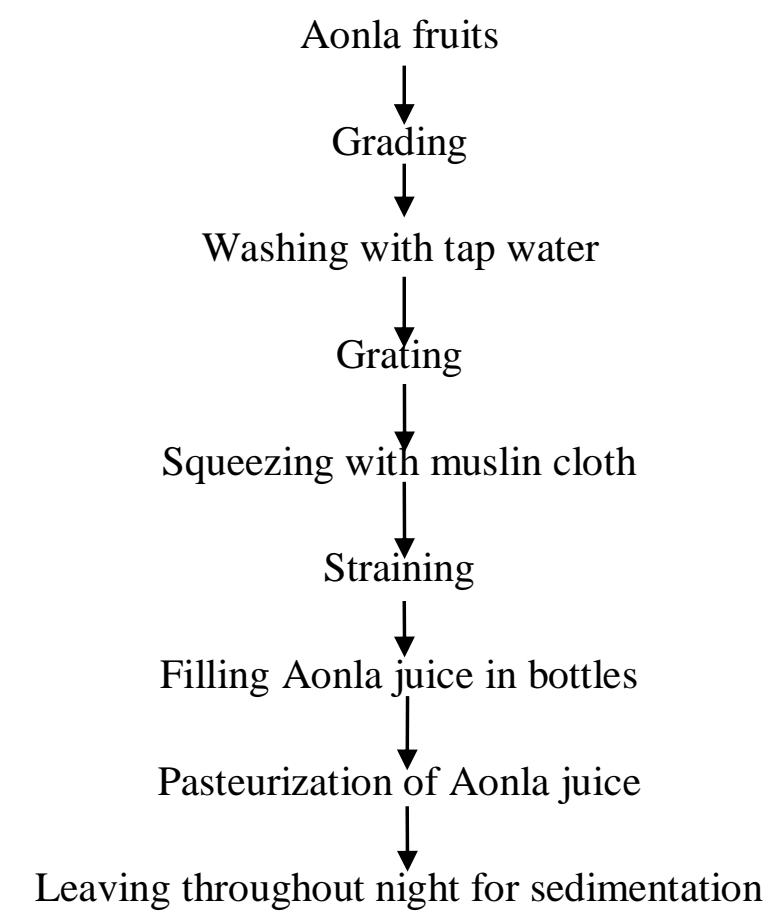

Fig.1 Flow sheet for extraction of aonla juice

Mature aloe vera leaves

Leaving for 24 hours in vertical position

Washing with tap water

Cutting into pieces

Extraction of gel by spoon

Homogenization through mixer

Staining through muslin cloth

Filling Aloe vera gel in bottles

Pasteurization ơf Aloe vera gel

Leaving throughout night for sedimentation

Fig.2: Flow sheet for extraction of aloe vera gel. 


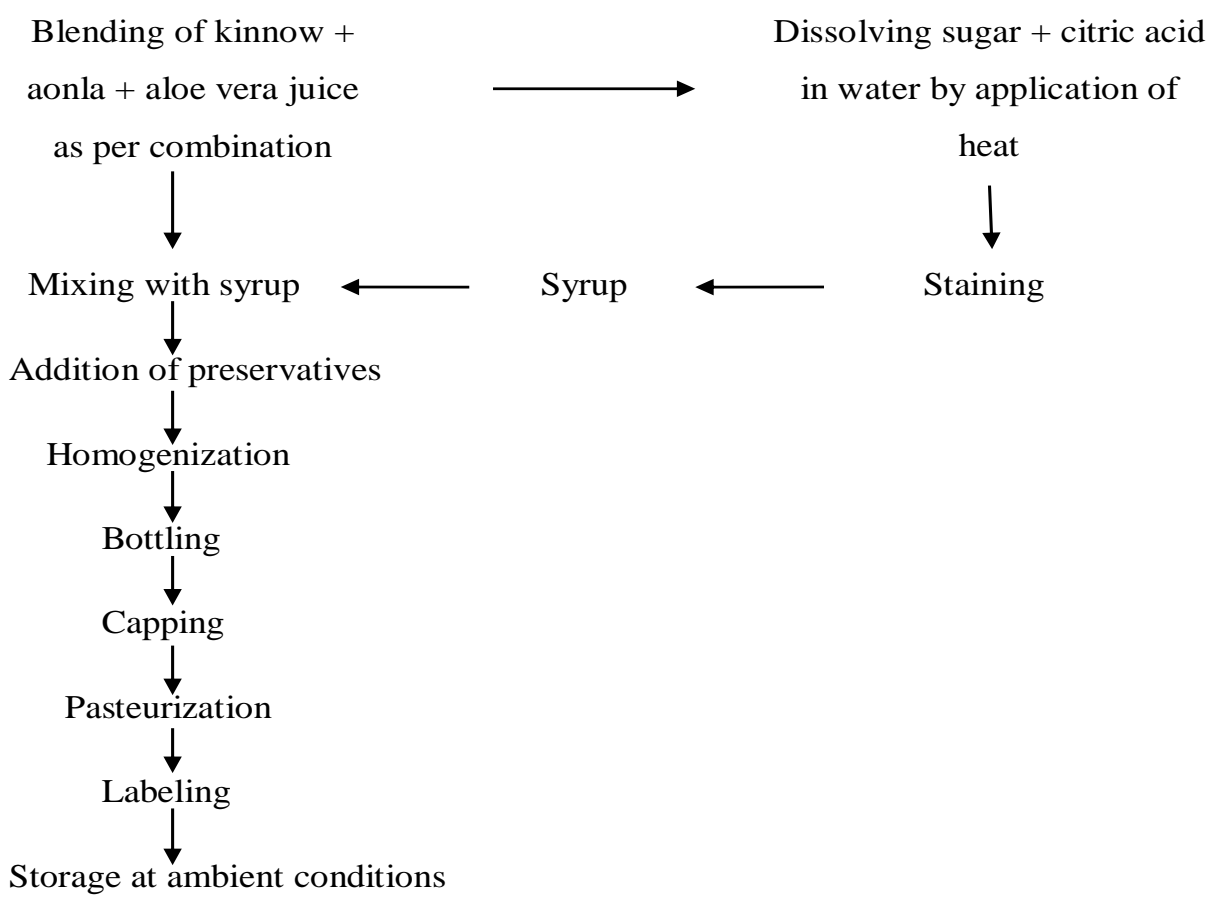

Fig.3: Flow sheet for preparation of kinnow-aonla-aloe vera blended squash.

Table.1 Standardization of blends for Kinnow-Aonla-Aloe vera blended squash

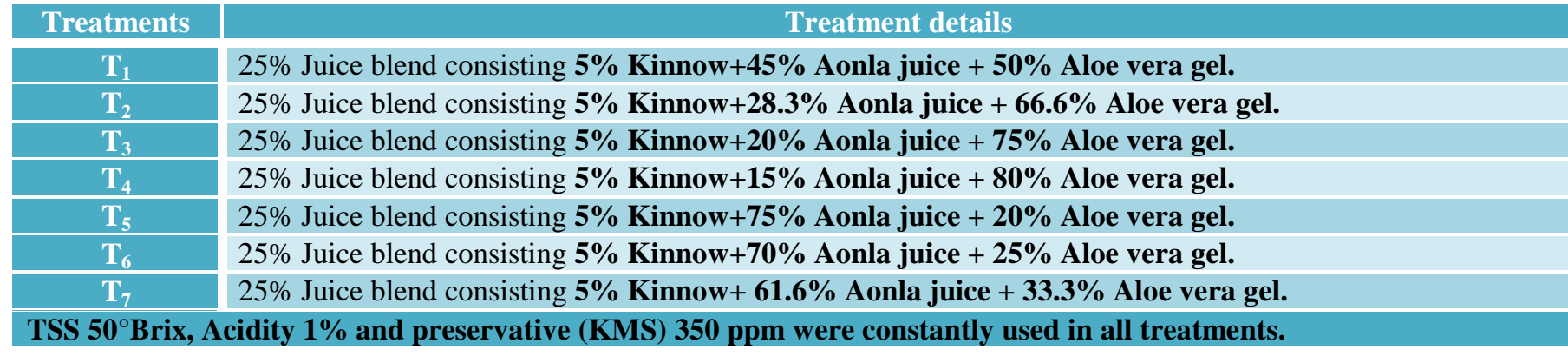

Table.4 Change in sensory score of over all acceptability of kinnow-aonla-aloe vera blended squash during storage at ambient conditions

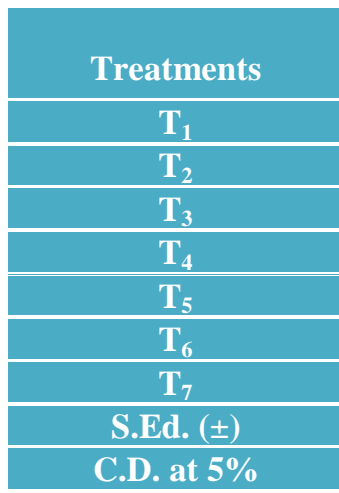

\begin{tabular}{|c|c|c|c|}
\hline \multicolumn{4}{|c|}{ Sensory Score of Overall acceptability } \\
\hline Initial value & $\mathbf{6 0}$ days & $\mathbf{1 2 0}$ days & Mean \\
\hline 7.33 & 7.00 & 6.67 & $\mathbf{7 . 0 0}$ \\
\hline 6.67 & 6.00 & 5.33 & $\mathbf{6 . 0 0}$ \\
\hline 7.00 & 6.67 & 6.33 & $\mathbf{6 . 6 7}$ \\
\hline 6.67 & 6.33 & 5.67 & $\mathbf{6 . 2 2}$ \\
\hline 6.33 & 5.67 & 5.00 & $\mathbf{5 . 6 7}$ \\
\hline 8.33 & 7.67 & 7.00 & $\mathbf{7 . 6 7}$ \\
\hline 7.67 & 7.00 & 6.33 & $\mathbf{7 . 0 0}$ \\
\hline 0.436 & 0.356 & 0.398 & \\
\hline 0.945 & 0.772 & 0.863 & \\
\hline
\end{tabular}


Table.2 Change in TSS ( ${ }^{\circ}$ Brix), acidity $(\%)$ and ascorbic acid (mg/100g) of kinnow-aonla-aloe vera blended squash during storage at ambient conditions

\begin{tabular}{|c|c|c|c|c|c|c|c|c|c|c|c|c|}
\hline \multirow[b]{2}{*}{ Treatments } & \multicolumn{4}{|c|}{ TSS ( ${ }^{\circ}$ Brix) } & \multicolumn{4}{|c|}{ Acidity (\%) } & \multicolumn{4}{|c|}{ Ascorbic acid (mg/100g) } \\
\hline & $\begin{array}{c}\text { Initial } \\
\text { value }\end{array}$ & $\begin{array}{c}60 \\
\text { days }\end{array}$ & $\begin{array}{c}120 \\
\text { days }\end{array}$ & Mean & $\begin{array}{c}\text { Initial } \\
\text { value }\end{array}$ & $\begin{array}{c}60 \\
\text { days }\end{array}$ & $\begin{array}{c}120 \\
\text { days }\end{array}$ & Mean & $\begin{array}{c}\text { Initial } \\
\text { value }\end{array}$ & $\begin{array}{c}60 \\
\text { days }\end{array}$ & $\begin{array}{c}120 \\
\text { days }\end{array}$ & Mean \\
\hline $\mathbf{T}_{1}$ & 50.00 & 50.43 & 51.00 & 50.48 & 1.01 & 1.35 & 1.71 & 1.36 & 48.15 & 43.22 & 36.81 & 42.73 \\
\hline $\mathbf{T}_{2}$ & 50.03 & 50.50 & 51.27 & 50.60 & 1.02 & 1.28 & 1.71 & 1.34 & 32.34 & 28.11 & 21.10 & 27.18 \\
\hline $\mathbf{T}_{3}$ & 50.03 & 50.50 & 51.30 & 50.61 & 1.02 & 1.27 & 1.68 & 1.32 & 24.40 & 20.39 & 13.37 & 19.39 \\
\hline $\mathbf{T}_{4}$ & 50.07 & 50.63 & 51.37 & 50.69 & 1.01 & 1.28 & 1.59 & 1.29 & 19.71 & 15.52 & 8.42 & 14.55 \\
\hline$T_{5}$ & 50.03 & 50.47 & 50.97 & 50.03 & 1.01 & 1.44 & 1.85 & 1.43 & 76.62 & 72.23 & 65.14 & 71.33 \\
\hline$T_{6}$ & 50.03 & 50.43 & 50.87 & 50.44 & 1.02 & 1.44 & 1.86 & 1.44 & 71.87 & 67.44 & 60.24 & 66.52 \\
\hline $\mathbf{T}_{7}$ & 50.03 & 50.40 & 50.93 & 50.45 & 1.01 & 1.36 & 1.72 & 1.36 & 63.94 & 59.52 & 52.68 & 58.71 \\
\hline S.Ed. ( \pm$)$ & 0.042 & 0.066 & 0.073 & & 0.013 & 0.011 & 0.013 & & 0.033 & 0.35 & 0.027 & \\
\hline C.D. at $5 \%$ & N/A & 0.144 & 0.158 & & N/A & 0.024 & 0.028 & & 0.071 & 0.758 & 0.057 & \\
\hline
\end{tabular}

Table.3 Change in reducing sugar (\%), non-reducing sugar (\%) and total sugar (\%) of kinnow-aonla-aloe vera blended squash during storage at ambient conditions

\begin{tabular}{|c|c|c|c|c|c|c|c|c|c|c|c|c|}
\hline \multirow[b]{2}{*}{ Treatments } & \multicolumn{4}{|c|}{ Reducing sugar (\%) } & \multicolumn{4}{|c|}{ Non-Reducing Sugar (\%) } & \multicolumn{4}{|c|}{ Total sugar (\%) } \\
\hline & $\begin{array}{l}\text { Initial } \\
\text { value }\end{array}$ & $\begin{array}{c}60 \\
\text { days }\end{array}$ & $\begin{array}{c}120 \\
\text { days }\end{array}$ & Mean & $\begin{array}{c}\text { Initial } \\
\text { value }\end{array}$ & $\begin{array}{c}60 \\
\text { days }\end{array}$ & $\begin{array}{c}120 \\
\text { days }\end{array}$ & Mean & $\begin{array}{c}\text { Initial } \\
\text { value }\end{array}$ & $\begin{array}{c}60 \\
\text { days }\end{array}$ & $\begin{array}{c}120 \\
\text { days }\end{array}$ & Mean \\
\hline $\mathbf{T}_{1}$ & 9.51 & 11.23 & 14.02 & 11.59 & 36.56 & 36.04 & 35.32 & 35.97 & 46.07 & 47.27 & 49.34 & 47.56 \\
\hline $\mathrm{T}_{2}$ & 9.49 & 11.20 & 14.01 & 11.57 & 36.54 & 36.04 & 35.29 & 35.96 & 46.03 & 47.24 & 49.30 & 47.52 \\
\hline $\mathbf{T}_{3}$ & 9.47 & 11.18 & 13.98 & 11.54 & 36.54 & 36.01 & 35.27 & 35.94 & 46.02 & 47.19 & 49.25 & 47.49 \\
\hline $\mathbf{T}_{4}$ & 9.45 & 11.14 & 13.94 & 11.51 & 36.54 & 36.03 & 35.30 & 35.96 & 45.99 & 47.17 & 49.24 & 47.47 \\
\hline $\mathbf{T}_{5}$ & 9.55 & 11.29 & 14.05 & 11.63 & 36.59 & 36.09 & 35.42 & 36.03 & 46.14 & 47.39 & 49.47 & 47.67 \\
\hline$T_{6}$ & 9.55 & 11.28 & 14.06 & 11.63 & 36.57 & 36.08 & 35.37 & 36.01 & 46.12 & 47.36 & 49.43 & 47.64 \\
\hline $\mathbf{T}_{7}$ & 9.51 & 11.22 & 14.07 & 11.60 & 36.59 & 36.09 & 35.32 & 36.00 & 46.11 & 47.31 & 49.39 & 47.60 \\
\hline S.Ed. $( \pm)$ & 0.008 & 0.015 & 0.015 & & 0.017 & 0.018 & 0.022 & & 0.013 & 0.015 & 0.009 & \\
\hline C.D. at 5\% & 0.018 & 0.033 & 0.032 & & 0.037 & 0.039 & 0.047 & & 0.029 & 0.034 & 0.019 & \\
\hline
\end{tabular}


Similar decreasing trend for ascorbic acid contents in Vitamin $\mathrm{C}$ enrichment of fruits juice based ready to serve beverages through blending of Indian gooseberry juice was also reported by the (Jain et al., 2004) and Vikram et al., 2014 in aonla candy. Similar result was reported by Jaiswal et al., (2008). Highest acidity in aspartame treated sample was due to acidic nature of aspartame. There was gradual increase in acidity in all treatments during storage up to 120 days. Increase in acidity with storage time in the ready ti serve beverages from aonla fruits was also reported by Aggarwal and Sandhu (2003) in kinnow juice and Chandan et al., (2010).

Reducing sugar of the squash was observed to be increased gradually up to the end of experiment in all treatments under ambient storage conditions. Similar result was reported by Garge et al., (2008). A sharp increase in reducing sugar of all treatments was found at later stage of the experiment (i.e. 90 and 120 days). Changes in reducing sugars were found statistically significant up to end of experiment.

Non-reducing sugar of the squash was observed to be decreased gradually up to the end of experiment in all treatments under ambient storage conditions. Similar result was reported by Garge et al., (2008). A sharp decrease in non-reducing sugars of all treatments was found at 0,60 and 120 days of the experiment. Changes in non-reducing sugar were found statistically significant up to end of experiment. Total sugar of the squash was observed to be increased gradually up to the end of experiment in all treatments under ambient storage conditions. Similar result was reported by Garge et al., (2008). A sharp increase in total sugars of all treatments was found at 0,60 and 120 days of the experiment. Changes in total sugar were found statistically significant up to end of experiment (Table 3).
Overall acceptability was influenced significantly with the kinnow-aonla-aloe vera blended squash treatment. Higher level of herbal extract could not produce top acceptability due to deviation from standard colour, texture, flavour and taste of the product retained after $4^{\text {th }}$ month of storage is presented in (Table 4). Though, the best result was recorded $(7.67$ score $)$ in $\mathrm{T}_{6}$. No certain pattern was observed with overall acceptability with treatment concerned.

The present investigation it is concluded that the treatment combination $5 \%$ Kinnow $+70 \%$ Aonla juice $+25 \%$ Aloe vera gel was found to be the most suitable in terms of quality and sensory scores was remained acceptable up to 4 months (120 days) under ambient storage conditions.

\section{References}

Aggarwal, P. and Sandhu, K.S. (2003). Effect of harvesting time on physico chemical properties of kinnow juice and non juice compounds of kinnow. J. Food Sci. Tech., 40: 666-668.

AOAC (1995). Official Methods of Analysis (16th Edn.), Association of Official Analytical Chemists, Washington, USA.

Boghani AH, Raheem A, Hashmi S. (2012). Development and Storage Studies of Blended Papaya-Aloe vera Ready to Serve (RTS) Beverage. J. Food Process \& Technol. 3: 1-4.

Cardoso, J.M.P. and Bolini, H.M.A. (2007). Different sweeteners in peach nectar: Ideal and equivalent sweetness. Food Res. Int., 40: 1249-1253.

Chandan, K., Prashanth, S.J., Nataraj, S.K., Indudhara, S.M., Rokhade, A.K. (2010). Preparation of dehydrated slices and RTS beverages from aonla (Emblica officinalis Gaertn.) fruits. Int. J. Agric. Sci., 6: 300-304. 
Deka, B.C., Sethi, V., Suneja, P. and Srivastava, V.K. (2004). Studied on physico-chemical change of lime-aonla spiced beverage during storage. Journal of Food Science and Technology (Mysore). 41 (3): 329-332.

Fisher, R. A. (2007). Statistical Methods for Researches Workers. Cosmo Publications, New Delhi.

Freed, M. (1966). Methods of Vitamin Assay. Inter Science Pub. Inc., New Yark.

Gaikwad KK, Singh S, Shakya BR. (2013). Studies on the Development and Shelf Life of Low Calorie Herbal AonlaGinger RTS Beverage by Using Artificial Sweeteners. J. Food Process \& Technol. 4: 1-4.

Garg, V., Barwal, V.S. and Sarera, S. (2008). Preperation and evaluation of vitamin $\mathrm{C}$ enriched fruit drink. Journal of Food Science and Technology (Mysore). 45 (6): 524-526.

Jain S., Sankhla, A.P.K., Dashora, A. and Sankhla, A.K. (2003). Physiochemical and sensory properties of orange drink. J. Food Sci. Tech. India. 40: 656-659.

Jain S.K., Khurdiya D.S. (2004). Vitamin C enrichment of fruit juice based ready-toserve beverages through blending of Indian gooseberry (Emblica officinalis Gaertn.) juice. Plant Foods Hum. Nutr. 59: 63-66.

Jaiswal, R., Singh, G. and Singh, A.K. (2008). Evaluation of aonla (Emblica officinalis Gaertn.) cultivars for squash making. Prog. Agri., 8 (1): 29-31.

Khan K.H. (2009). Roles of Emblica officinalis in Medicine - A review, Bot. Res. Int., 2: 218-228.

Madhuri S., Pandey G., Verma K.S. (2011). Antioxidant, immunomodulatory and anticancer activities of Emblica officinalis: an overview, Int. Res. J. Pharm. 2: 38-42.

Malhotra, R., Tyagi, S.M. and Saini, P. (2010). Studied on aloe vera a component of functional foods. Beverage and Food World. 37 (7): 3639.

Morten, C., Meilgaard, B. and Thomas, C. (2010). Sensory Evaluation Techniques, Fourth Edition. CRC, Press LLC, 2000 N.W. Corporate Blvd., Boca Raton, Florida. 33431.

Nchez-moreno C, Plaza L, Adeancos B. and Pilarcano M. (2003). Vitamin C, Provitamin A, Carotenoids and Other Carotenoids in High-Pressurized Orange Juice during Refrigerated Storage. J. Agric. Food Chem., 51: 647653.

Panse, V.G. and Sukhatme, P.V. (1967). Statistical methods for agricultural workers. Indian Council of Agricultural Research, pp. 381-385.

Priyanka, N., Dileep, K.T. and Devendra, K. B. (2012). Study on changes of nutritional and organoleptic quality of flavored candy prepared from aonla (Emblica officinalis G.) during storage. International J. Nutrition and Metabolism. 4: 100-106.

Ram, R. B., Meena, M.L., Sonkar, P., Lata, R. and Upadhyay, A.K. (2011). Standardization and evaluation of blended aonla (Emblica officinalis Gaertn.) and bael (Aegle marmelos Correa) RTS beverages, Plant Arch. 11: 205-208

Ranganna, S., (2001). Sugarestimation. In: Ranganna, S. (Ed.), Handbook of Analysis and Quality Control for Fruit and Vegetable Products, 2nd ed. Tata McGraw-Hill, New Delhi, pp.12-17.

Sasi, K.R., Ray, R.C., Paul, P.K. and Suresh, C.P. (2013). Development and storage studies of therapeutic ready to serve made from blend of Aloe vera, aonla and ginger juice. J. Food Process Technol. 4: 255-266.

Satwadhar, P.N., Deshpande, H.W., Syed, I.H. and Syed, K.A. (2011). Nutritional 
Composition and Identification of Some of the Bioactive Components in Morinda citrifolia Juice. Int. J. Pharm Pharm Sci., 3: 58-59.

Sowjanya, G., Rokhada, A.K., Madalageri, M.B., Swamy, G.S.K. and Patil, C.P. (2009). Preparation and storage of carbonated ready to serve (RTS) pomegranate beverage. Beverage and Food World. 36: 30-32.

Vijay, K., Kore, T., Devi, L. and Kabir, J. (2013). Packaging, storage and value addition of aonla, an underutilized fruit, in India. Fruits. 68: 255-266.

Vikram, B. and Prasad, V.M. (2014). Studies on Value Added Kinnow - Aonla Blended Ready to Serve Beverage. $J$. Food Process Technol., 5: 288-292.

Vikram, B., Prasad, V.M. and Saroj, P.L. (2014). Comparative study of varieties, honey coating and storage durations on Aonla candy. Indian J. Hort., 71: 104108.

\section{How to cite this article:}

Balaji Vikram and Purnima Singh Sikarwar. 2018. Development and Evaluation of PhysicoChemical Properties of Kinnow - Aonla - Aloe Vera Blended Squash. Int.J.Curr.Microbiol.App.Sci. 7(04): 113-122. doi: https://doi.org/10.20546/ijcmas.2018.704.013 